\title{
Preface: Judaism as a Philosophical Way of Life
}

I am not a particularly Jewish thinker. I am just a thinker.

—Emmanuel Levinas

Another book on Emmanuel Levinas? In the context of the incomplete and still unpredictable "return of religion" to academic and public discourse, the work of Levinas becomes more pertinent, even as criticism of it becomes more caustic. As the interaction but also the tension between the religious and the secular increases, Levinas stands out among modern thinkers for the original way he weaves together the religious and the secular without opposition. In 1922, Carl Schmitt formulated his now well known dictum that "all the significant concepts of the theory of the modern state are secularized theological concepts." ${ }^{\text {"1 }}$ According to this view, the contemporary deployment of concepts such as sovereignty, fraternity, legality, right, and enemy in the context of modern secular political life is best understood in light of the distinctly religious intellectual heritage that gave rise to them. Indeed, the unavoidable use we make of such concepts involves a repetition of that religious heritage in a secular key. Secularization would mark less a break with our religious heritage than its extension to a new historical situation. The assumption of this book is that a similar phenomenon applies to fundamental secular moral concepts and, therefore, that the best way to understand such concepts is by exploring the religious intellectual heritage that they secularize. Immanuel Kant's moral philosophy is often taken as a paradigmatic example of the secularization of an essentially Christian conception of morality (more precisely, a Protestant Prussian conception). This book advances a similar claim about Levinas's work, with two crucial differences. First, Levinas's account of ethics is phenomenological, and so to understand the religious heritage at work in what he calls ethics we need to understand not simply the religious concepts it secularizes but the way it transforms fundamental religious 
experiences into ethical intuitions. Second, the secularization at work in Levinas's account of ethics is best understood in relation to the particular religious heritage in which he thought, a heritage that is first and foremost Judaic but also, more generally, Judeo-Christian. Not that the religious dimension of Levinas's thought ever went unnoticed. On the contrary, it was from the outset the subject of complex and spirited debate, beginning with Jacques Derrida's seminal 1967 essay, "Violence and Metaphysics." In more recent years, several interesting studies have commented on, and sometimes vigorously critiqued, the religious aspect of Levinas's thought. And yet most of the debate has circled around the vague notion of religion without due consideration of the concrete and particular religious character of his thought. But Levinas, who was born in 1906 into the Russian-Jewish haskalah (enlightenment) milieu of Kaunas, Lithuania, was a committed Jew for the duration of his adult life, and his philosophical account of "religion" is distinctively Judaic.

The aim of this book is to provide an interpretation of Levinas's philosophy from the Judaic heritage he was secularizing. Such an interpretation is crucial for a proper understanding of Levinas's work, but its significance extends beyond these exegetical concerns. By proposing an interpretation of Levinas's philosophy from the sources of Judaism, I raise in this study broader questions concerning the nature and scope of both philosophy and Judaism. By relying on a philosophical interpretation of Judaism, Levinas expands the significance of this particular tradition beyond the conventional social, historical, and legal limits of being Jewish. In so doing, he provides an interpretation of Judaism addressed to the Gentiles, or to Jews and Gentiles alike. In this sense Levinas's enterprise recalls that of Paul, the first apostle to the Gentiles, who likewise interpreted the sources of Judaism for the nations at large.

I will argue that Levinas's philosophical claims are saturated by interpretations of Judaism. But if Levinas's philosophy depends on Jewish texts and traditions, does this not compromise its claims? What sort of philosophical status does this work have if it is generated out of a particular-indeed, a particularistic — tradition, such as Judaism? It was, of course, Martin Heidegger, Levinas's most important philosophical influence and an unrepentant member of the Nazi party, who placed hermeneutics at the center of modern philosophy. Levinas learned many things 
from Heidegger, but for our purposes two of them should be emphasized. First, Levinas accepted Heidegger's fundamental claim that thinking itself is an interpretative engagement with the intellectual heritage that constitutes the historical situation of the philosopher. With Heidegger, philosophy becomes hermeneutics, a thoughtful disclosure of the "meaning of being" that severely modifies the old philosophical questions (those concerned with relations among truth, knowledge, reality, values, mind, nature, time, and space) by approaching them as the nexus of a historical situation. There is no avoiding the fact that Levinas's philosophical approach to Judaism-his understanding, interpretation, and application of the Judaic tradition-is primarily indebted to the Heideggerian breakthrough, chiefly for the way it foregrounds the interpretative character of thought itself. Second, as Heidegger himself understood, the argument of Being and Time leads to a "post-metaphysical" way of doing philosophy guided by the conviction that "Being" (whatever that is) cannot be approached in terms of its correspondence to a concept or a representation and cannot be analyzed as an object-like phenomenon or set of phenomena, but instead gives itself to us without becoming a ground or principle from which a stable, metaphysical picture of the world could be derived. If "Being" in the preceding sentence reminded some thinkers of an old god called YHWH, that is either a coincidence (as Heidegger thought) or a call "to hear a God not contaminated by Being" (as Levinas thought). ${ }^{2}$ Consequently, the assumption of this book, that Levinas's philosophical work is based on an interpretation of Judaism, leads to a dialogue, a confrontation, and an implication between a certain Judaism, a certain Paul, and a certain Heidegger, and thereby raises complex and at times painful questions.

Levinas's biography is inextricably bound to the turbulence of the European twentieth century. The Russian Revolution, the aftermath of the Dreyfus affair, the I930s, and the Holocaust touched Levinas personally, vocationally, and intellectually. His philosophical output commenced in 1929 with pioneering studies of Husserlian phenomenology, and his first publications on issues relating to Judaism began with "Some Reflections on the Philosophy of Hitlerism" in 1934. By the time of his death in 1995 Levinas had produced a corpus of major philosophical writings, most of it concerned with "ethics," as well as six collections of philosophical commentary on Jewish texts such as the Hebrew Bible, the Talmud, 
and works by medieval and modern Jewish thinkers. While clearly working on two fronts throughout his life, Levinas sought to distinguish his "confessional" writings from his strictly philosophical work by publishing each with separate presses and denying, in several published interviews and discussions, that his philosophy was in any way based on faith. Such safeguards are commonly deployed among French philosophers of various religious persuasions. The French tradition of lä̈cité separates not only the state but also its philosophers from religion; it is in fact forbidden to teach theology at almost all universities of the French Republic. Like many of Levinas's colleagues, such as Paul Ricoeur or, more recently, Jean-Luc Marion, Levinas accepted the rules of the game of French philosophy and went to lengths to downplay or even deny the religious element of his thinking. If that is a common stance of Christian philosophers whose religion tacitly pervades the French intellectual milieu, for Levinas it was indispensable. Denying the Jewish element of his thought was quite simply the price of its admission into the arena of French philosophy. Yet several points militate against separating the philosophy from the Judaism.

The most obvious is that Levinas himself articulated the same philosophical views, or what amounts to the same views, in both his confessional and his philosophical works. If scholars of the Talmud have been surprised that Levinas finds hidden poststructuralist intentions in the debates of Abbaye and Rabba, contemporary philosophers have been concerned by his occasional citation from and copious allusions to Jewish texts and ideas in his philosophical corpus. Maintaining his stance as a philosopher, Levinas nevertheless acknowledged an "infiltration" from Judaism to his philosophy. ${ }^{3}$ Moreover, unlike so many of his Nietzschean colleagues on the Continent, Levinas never thought that either God or religion is dead. That conviction was reinforced by a desire to affirm a certain Judaism after the Holocaust, which claimed his parents, brothers, and most other Jews of Kaunas. The visceral effect of the destruction of European Jewry on Levinas's thinking is impossible to deny, even if its explicit presence in his work is more difficult to determine. ${ }^{4}$ But even before and independently of the Destruction, Levinas's existential commitment to Judaism was palpable.

After all, his early years were spent shuttling between the elite intellectual culture of interwar Paris - at the soirees of Gabriel Marcel and 
the colloquia of Jean Wahl, in company with the likes of Alexandre Kojève, Jean-Paul Sartre, Maurice Merleau-Ponty, and Maurice Blanchotand his day job as an administrator of the Alliance Israélite Universelle, a Jewish teachers' college charged with educating Jews from the French Mediterranean colonies. Although his pioneering study as a brilliant twenty-four-year-old master's student was published in 1930 to prizewinning acclaim ${ }^{5}$ - the book introduced the immensely influential German phenomenological movement to young French philosophers such as Sartre, Ricoeur, and, later, Derrida-Levinas was, for thirty years to come, a lay philosopher employed in a largely administrative role in the field of Jewish education. While fascism spread through Europe during the I930s, he read Moses Maimonides' Guide for the Perplexed and Franz Rosenzweig's The Star of Redemption and published several articles in the all-too-rare genre of Jewish philosophical journalism, including the essay on the philosophy of Hitlerism and a related discussion on "The Contemporary Relevance of Maimonides." ${ }^{6}$ For almost five years, from June I940 until the end of World War II, Levinas was incarcerated as a French POW in Stalag IX-B in the region of Hannover, along with other Jewish soldiers protected by the Geneva Conventions. By day he labored as a woodcutter and by night he read-G. W. F. Hegel, Marcel Proust, and Jean-Jacques Rousseau, among others-and composed an important philosophical fragment on "the horror of existence" that was evidently as much shaped by his view of the war as by his analysis of Hegel and Heidegger, against whom he argues. ${ }^{7}$ Upon returning to Paris after the war at the age of forty, Levinas characteristically expressed his dual loyalty to philosophy and Judaism. Among the first things he did was to extend the philosophical fragment he had composed during captivity into a superb phenomenological essay, From Existence to the Existent (1947), and to deliver a series of lectures, later published as Time and the Other, at the College Philosophique established by Wahl. Another was to assume the position of director of a prestigious Jewish high school, the École Normal Israélite Orientale. Many years later Levinas confessed that working as an administrator at a Jewish educational institution instead of forging an academic career was a vocational decision: "After Auschwitz ... I was responding to a historical calling. It was my little secret." ${ }^{8}$ Like Levinas's commitment to Jewish education, the role of Judaism in his general 
philosophy is also a little secret, even if the philosopher was not much good at keeping secrets.

It was during these years, from 1946 to 1961, that Levinas composed his first major philosophical account of ethics-in lectures, articles, and essays that culminated in his first magnum opus, Totality and Infinity (I96I), the work that also earned him his doctorat d'Etat, a prerequisite for teaching philosophy at a French university. During this same period of productive philosophizing, Levinas began studying the Talmud with a brilliant and enigmatic teacher, Monsieur Chouchani; delivered weekly Shabbat lessons on Rashi's classical commentary on the Torah (from the eleventh century, but largely based on important rabbinic commentaries from Talmudic times); and involved himself in the rituals of Shabbat, including the synagogue liturgy. By 1960 he was sufficiently emboldened to present his first "Talmudic Reading," which he would do again for most of the next thirty years at the annual Colloquium of French Jewish Intellectuals that he helped found; apparently he would often consult Maimonides' legal code, the Mishneh Torah, in order to select a Talmudic passage to suit the conference theme.' Such incidental biographical details must be recalled because the sources of Levinas's Judaism determine the shape it assumes in his philosophical work. It is particularly important to bear in mind the significance of the close, prolonged exposure Levinas received to canonical Jewish texts, in Hebrew, through the liturgy of Judaism, ${ }^{10}$ as well as the education in rabbinic lore he received from Rashi, Maimonides, Hayim Volozhin, Chouchani, and contemporary scholars such as Gershom Scholem. Although Levinas surely never received a formal advanced Jewish education, neither of the academic nor of the yeshiva variety, he embraced the intellectual heritage of Judaism: the Hebrew Bible, rabbinic commentaries, medieval masters (those just mentioned, but also Judah Halevi and Solomon Ibn Gabirol), and modern Jewish philosophers from Moses Mendelssohn to Hermann Cohen, Martin Buber, and Rosenzweig. Even those who accept Levinas's claim that his philosophy stands independently of his Judaism do not for a moment separate the philosopher from the Jew. It was only at the age of fifty-seven, in 1963, that Levinas assumed his first appointment as a philosopher. ${ }^{11}$ Perhaps he thought of professional philosophy as a form of early retirement. In any case, the argument of this book is that one cannot separate Levinas's work from its Jewish provenance, even though the phi- 
losopher enjoined his readers to do so. Levinas was a remarkably creative and original thinker as well as a broad and penetrating reader, and it must be borne in mind that during this intensely fertile period from after World War II to his first appointment as a professional philosopher, he was all the while thinking of Judaism philosophically and philosophy Judaically. Accordingly, despite his attempt to regulate our reading of his work by partitioning the Judaic from the philosophical, what is required, rather, is to determine the contours of the profound unity of Judaism and philosophy to which his thought attests.

Since I hope some readers of this book will come from Jewish studies and religious studies generally and therefore may not have read much of Levinas's major philosophical works, I will briefly elucidate his core philosophical idea, although I make no claim whatsoever to offer an "introduction to Levinas," of which by now there are numerous. ${ }^{12}$ Levinas's project is best understood, at least provisionally, as an attempt to formulate a post-Heideggerian account of ethics that draws its inspiration from Kantian morality while avoiding the critique of Kant waged by Heidegger. For Levinas, following Kant, ethics involves a sense of categorical obligation, obligations that rely on no particular moral feeling or empathy and no personal interest or gain. Levinas's constant use of heady terms like "transcendence" and "infinity" or "otherwise" and "beyond" was driven by a desire to articulate the view that moral obligation is an "end in itself," as Kant called it, an ultimate term of reference that cannot be reduced to more basic conceptual language such as "biology" or "ontology" or "instrumental reason." Levinas was largely right in his perception that Heidegger had sought to destroy the very ground of this Kantian view of morality, even if Levinas's interpretation of Being and Time was also influenced by its author's accommodation to Nazism. The young Jewish philosopher was among the first to promote Heidegger's groundbreaking work, published in 1927. By 1934, however, his enthusiasm for Being and Time had already been tempered by the realization that Heidegger's political commitments were not accidentally related to his philosophical views. For reasons that are not pondered often enough, Levinas's critique of Heidegger focused almost entirely on the moral rather than the political flaws of Being and 
Time. At the end of this book I suggest that this exclusive attention to Heidegger's critique of morality did not prevent Levinas from repeating some of the fundamental problems of political ontology. At that point I confront the question of the politics of Levinasian ethics, a question made more acute by interpreting Levinas Judaically. For now, though, let me clarify the quasi-Kantian critique of Heidegger that led Levinas to develop his distinct sense of "ethics."

According to Levinas, Heidegger had subordinated and devalued ethics within his philosophical project by historicizing and instrumentalizing it. After World War II this became not merely a theoretical argument but one that Levinas waged against the culture of modern Western morality in which ethics was commonly dismissed by intellectuals as merely relative, ideological, or emotive. In place of such prevalent ideas Levinas sought to revive the Kantian view that morality was categorically binding and that to fail to heed a moral imperative is to miss something crucial about the ultimate structure of reality. And yet for Kant, the categorical nature of morality was derived from a view of the fundamentally rational nature of human beings. It is only because human beings have the capacity to conform their will to Reason that morality, according to Kant, is possible. Heidegger argued against just this notion of human nature. In his view, Kant's notion of the transcendence of Reason is itself based on prior "ontological" conditions that are neither purely rational nor particularly moral, conditions that constitute our being-in-the-world temporally (such as sociality, historicality, language, and much else). $\mathrm{He}$ showed that morality could not be explained by appeal to the rational nature of humanity and that the idea of the human as a fundamentally rational being, and thus the idea of rational morality, was but a contingent, historical, and even "inauthentic" interpretation of the experience of conscience (Gewissen). According to Being and Time, the truth of conscience lies not in conforming one's will to the universal law of Reason but in the disclosure of the finitude of one's concrete situation. In Heidegger's view, the very idea of absolute moral imperatives is merely an inauthentic interpretation of a much more fundamental experience of the finitude of being, which is itself ethically neutral. This ontological reduction of Reason to the fundamental horizon of being-in-the-world historicizes and relativizes morality. It exorcises the very idea of immutable moral values 
based on the free and rational inner nature of the human will. Worse, Heidegger argued that the notion of a "public conscience" belonged to the realm of "inauthentic" existence. ${ }^{13}$ Experiences of guilt or conscience that are interpreted according to universal "values" or derived from formal reasoning are "ontologically inadequate." ${ }^{14}$ For Heidegger, morality is but a set of platitudes reified by a particular community at a particular historical moment and misconstrued by inauthentic individuals as the authoritative grounds for action or a guilty conscience. We might say that for Heidegger, Kantian morality is but common cant. From these ruins of Kant's categorical morality Levinas sought to restore a new sense of an unconditional ethical imperative that could not be dismissed as merely abstract, formal, ahistorical, inauthentic, and ontologically inadequate. He did this by developing a phenomenology of the moral imperative that was derived not from the fact of Reason but from the face of the Other. This account of a pre-rational but still categorical imperative constitutes his signature contribution to contemporary phenomenology and moral philosophy.

It should be noted how Levinas's attempt to describe a post-Heideggerian account of ethics that preserves the categorical nature of moral imperatives involves a fundamental acceptance of Heidegger's critique of Kantian anthropology and epistemology. Kant constructs morality on the basis of a metaphysical view of the primacy of Reason and of the freedom of the human will to conform to it, but for Levinas ethics is generated out of the immediate, concrete expression of the mortality, vulnerability, and singularity of the other person, metaphorically encapsulated in "the face." This account of "ethics" therefore looks quite different from much contemporary moral philosophy and from its Kantian progenitor. ${ }^{15}$ In place of arguments that appeal solely to reason, Levinas provides descriptions that seek to "awaken" our pre-rational moral sensitivity to others. For Levinas, it is not the universal form of reason but the singular manifestation of the other that has moral authority in the modern world. Many of his descriptions of ethics, what can loosely be called his "phenomenological" method, aim to show how the relationship between self and other is the very condition, or the foundation, for there being an intelligible world at all. These descriptions are meant to explain why it is that "ethics" is our ultimate transcendental condition (in the Kantian sense), which is to say 
that ethics is the condition for the possibility of meaningful experience as such. But contrary to Kant, Levinas maintains that it is not the formal concept of morality that generates its exalted significance but its material presentation in the encounter with the other as a singular figure, a face, or a proper name.

We can point to three features of Levinas's account of ethics that distinguish it from most moral philosophy. First, in his view, ethics makes demands calling for an individuated responsiveness that he calls "responsibility." The ethical response must be radically individuated because it relates directly to the concrete person whom one encounters rather than some preconceived idea of human nature. The uniqueness of the other calls for a singular ethical response on the part of oneself; indeed, it calls one to become oneself by implicating one's own "identity" in the relationship to the other, a relationship that Levinas insists is ethical. Why does the relationship to the other have a specifically ethical sense? Why is this relationship characterized as fundamentally ethical rather than as biological, ontological, or instrumental? Levinas's answer, which we will modify in the course of this book, is that the uniqueness of the other presented in his or her "face" cannot be approached without ethics. The face is never equivalent to a phenomenon seeking to be seen or described, or to a set of concepts or narratives that are to be explained or understood. The face cannot be captured by description, explanation, or narration; it can only be respected or desired, loved or hated. To exclude the ethical significance of the face is to miss what makes it unique. The face thus presents a distinctly ethical excess that neither perception nor cognition, neither epistemology nor semantics, neither biography nor psychology can contain. Ethics involves the "mutation" of ordinary experience and "the opening of a new dimension" in which the face exposes an ethical obligation that cannot be articulated in terms of reasons, causes, or rules (TI, I97/TeI, I72). ${ }^{16}$ Levinas's customary way of indicating the distinctly ethical sense of the face is to argue that language "reduces" - in the technical phenomenological sense of leading back to a primordial manifestation-to the vocative case, to the occasion of direct address in which the "expression" of the face says more than what is conveyed by its semantic values, a distinction he regularly marks by the excess of "the saying" over "the said." It is here, in the ethical presentation of the face, beyond semantics, epistemology, and 
even manifestation, that "the person presents himself as unique" (TI, 66/ TeI, 37). Accordingly, although Levinas argues that "the face speaks," the point is that it speaks only ethically; its saying does not appear in the ordinary sense of a meaning made manifest to consciousness but only as a moral command- "Do not kill!" or "Love me!" "Give me!" or "Help me!"- -addressed to me in a manner than cannot be readily generalized.

A second distinctive feature of Levinas's view thus follows from the account of ethics as individuated responsiveness. Since ethics arises from the singular way in which one responds to the uniqueness of the other, it cannot be abstracted into a set of rules, values, or principles. It is therefore not a theory of ethics, as Derrida astutely observed, but an "Ethics of Ethics" that "does not seek to propose laws or moral rules, does not seek to determine $a$ morality, but rather the essence of the ethical relation in general." ${ }^{17}$ In Levinas's words, "The presentation of being in the face does not have the status of a value" (TI, 202/TeI, I77). Or as he rehearsed the idea in his second magnum opus, "Responsibility is what first enables one to catch sight of and conceive of value" (OB, I23/AE, I59). ${ }^{18}$ Levinas insists that ethics is as fluid, open, and even indeterminate as a human relationship itself. The language of ethics therefore involves "respect," "responsibility," and "obligation" rather than "rules," "principles," and "rights" because his principal point is not to argue for particular norms but to cultivate a sense of responsibility and indebtedness to the other that constitutes the very idea of oneself. That rights, procedures, and institutions will enshrine the ethicality of the other is a second-order moral and political requirement derived from the basic ethical experience of the other.

A third feature of Levinas's account is that ethics is not derivative of any more basic condition but is the very origin and opening of intelligibility. This is what he means by the bold assertion that "ethics is first philosophy" (TI, 304/TeI, 340). In his view ethics constitutes the basis of meaning in general, which is to say that all of our philosophical and nonphilosophical concerns-for knowledge and truth, for politics and economics, for science and art, for oneself and one's family, for eros and thanatos-are indebted and obliged to ethical relationships from the ground up. For Levinas, then, ethics is the individuated responsiveness to the singularity of the other that gives rise to meaning in general and to which one is indebted for one's "own" ultimate purpose and identity. Responsibility, or "response-ability," is 
not merely what one does but who one "is."

It will have been noticed that none of what I said in this brief explication of what Levinas calls "ethics" made any reference to Judaism, either to the biblical revelation of the Jews or to their commentaries, traditions, and history. Levinas wrote as a philosopher. The ethics he describes appeals to dimensions of human experience that presuppose none of Judaism's doctrinal beliefs and no commitments to its history, tradition, or destiny. Yet the claim of this book is that the descriptions Levinas makes of ethics draw from the Judaic tradition in a decisive way. The precise nature of the Judaism smoldering within Levinas's philosophy is admittedly not obvious, even if his thought binds Judaism and philosophy together at all its crucial sutures. The attempt to analyze these junctures thus requires a type of "reverse engineering" of Levinas's philosophical project that unbuilds its midrashic structure or unravels its numerous but unstated exegetical threads. As I turn the fabric of Levinas's philosophical works inside out we will discover the Judaic threads they have woven. If I am right, we will see that what is sometimes understood as an exercise in pure phenomenology is at the same time a coherent philosophy of Judaism. ${ }^{19}$

The task of interpreting Levinas's philosophy out of the sources of Judaism is inseparable from an analysis of the barely tested possibility that there may be such a thing as a philosophy of Judaism that is both philosophically and Jewishly rigorous. To be sure, Judaism and philosophy have long kept company; we find them intermingling in rapturous accord, briefly in Philo but pervasively in medieval and modern Jewish thought. Yet for most of its history Judaism has turned to philosophy only to shine the light of wisdom back onto itself. Maimonides' Guide of the Perplexed, like Joseph B. Soloveitchik's Halakhic Man, is infused with philosophy, but as with almost all examples of what is tellingly called "Machshevet Yisrael" — which refers to "the thought of the Jewish people" rather than Jewish philosophy-it is addressed solely to Jews. ${ }^{20}$ One of the great novelties of Totality and Infinity and Otherwise than Being or Beyond Essence is the possibility they herald of a philosophy of Judaism whose claims are not restricted or even addressed primarily to Jews. In this respect, Levinas's understanding of Judaism goes beyond the traditional practice of pouring philosophy into kosher vessels, 
with the standard boiling and souring of the vine. His is a much bolder venture that has been dared only on the rarest occasions - for example, in the epistles of St. Paul or the Fons Vitae of Ibn Gabirol, which likewise provide interpretations of Judaism for the nations of the world. ${ }^{21}$ In both these cases the new branch was lopped off; indeed, in both cases, all proportions aside, it was transplanted into Christianity. Throughout his life Levinas's work seemed destined for the same fate. For a long time his philosophical works were better known to Christian thinkers and postmodern philosophers than to those interested in "the thought of the Jewish people"; the latter often read only Levinas's Talmudic readings and essays on Judaism, if they read him at all. Contrary to this reception history, the wager of this book is that Levinas's philosophical works are midrashically determined from beginning to end. If I am right, then far from playing into the identity politics of "being Jewish," as Levinas has been accused of doing, his work confounds conventional identity politics and theoretical frameworks that continue to distinguish between Jew and Gentile, Israel and the nations, Jerusalem and Athens, and so on. I argue that although Totality and Infinity and Otherwise than Being are explicitly addressed to non-Jewish European philosophers, or Westerners generally, they nevertheless encode interpretations of Judaism in their core arguments. Indeed, despite the well-trodden path leading from a philosophical interpretation of Judaism to some determined account of a proper "Jewish identity," Levinas's calculated indifference to a philosophical account of Jewish identity is precisely what is needed today. Only a Judaism that goes beyond the identity politics of being Jewish is able to make a Judaic contribution to thinking about ethics and politics in our world today. This book, then, is a sometimes timorous, sometimes brazen act of giluy 'arayot, in both senses: an act of illicit union that desires to give birth to Judaism as a philosophical way of life and an exposure of the philosophical nakedness of Judaic spirituality.

In his outstanding historical study of Levinas's philosophy, Samuel Moyn has argued that its genesis should be understood within the context of a burgeoning interest in Protestant existential theology among the Parisian intelligentsia of the interwar period. Moyn entirely discounts the influence of the Judaic on Levinas's thinking and goes so far as to call Levi- 
nas's description of Judaism an "invention."22 Moyn's account thus seems to belie the basic assumptions and methods of this book. In Chapter I, I argue that Moyn brilliantly elucidates an understandable but unduly partial and ultimately mistaken perspective that does not account for the genuinely Judaic character of Levinas's philosophy. This exercise required me to analyze the meaning and possibility of a philosophy of Judaism, a possibility that is available precisely in the context of the post-Heideggerian hermeneutical philosophy in which Levinas operated.

In Chapter 2, I begin a sustained reading of Levinas's philosophy as a covert interpretation of certain aspects of classical Jewish thought. I argue that Levinas's phenomenological description of the emergence of subjectivity recapitulates the great myth in Genesis I, according to which creation takes place on the basis of the "unformed and void." Like the Priestly author in the Bible, Levinas argues that creation does not happen ex nihilo but is wrought from the chaos of the anonymous darkness of existence. Creation makes order out of chaos, but the chaos threatens to return, like a deluge or a holocaust, if the moral covenant is broken. Chapter 3 delves into Levinas's phenomenology of creation from an altogether different angle. Whereas Chapter 2 argued that Levinas provides a covert and secularized account of the fragility of creation that is sustained by covenantal fidelity (among people, of course), Chapter 3 explores the more classical notion of creatio ex nibilo as it appears in Levinas's work. I argue that Levinas's use of the term in its classical sense borrows from Maimonides and implies a thoroughly metaphysical conception of creation. Maimonides' argument is directed against Aristotle, but Levinas wages his argument against Heidegger. In both cases, however, it is a matter of the Jewish thinker arguing for the transcendence of freedom and responsibility for particularity. Levinas's critique of Heidegger is thereby read as a repetition of Maimonides' critique of Aristotle, a parallel buttressed by the well-known thesis that Being and Time is an ontological "translation" of Aristotle's Ethics.

After Chapter 3, I shift gears, for although Totality and Infinity can be read as a sustained midrash on creation, it remains, like the notion of creation itself, invested in a metaphysical account of agency and transcendence. Creation is a quintessentially metaphysical concept that implies a being at a distance from the world by virtue of its freedom. The Interlude 
shows how Levinas came to reject the notion of creation by opening a new direction for his later work to be read as a post-metaphysical secularized philosophy. Where formerly there was creation, Levinas's later, post-metaphysical work is a midrash on creatureliness. I argue that there is a seismic shift between the two great works, Totality and Infinity and Otherwise than Being, that leads Levinas from a metaphysical to a post-metaphysical account of ethics, correlative to similar distinctions invoked nowadays in philosophy and theology. The quite radical nature of this turn, which warrants speaking of Levinas I and Levinas 2, has not been sufficiently appreciated in the literature, although awareness of it is indispensable for answering most of Levinas's critics, almost all of whom attack his metaphysical views.

A traditional way of surpassing metaphysics is to turn from positive to negative theology. Chapter 4 argues that Otherwise than Being, in which Levinas develops his post-metaphysical position, is best understood as a work of negative theology, in particular of Judaic ethical negative theology. I therefore turn again to Maimonides in this chapter, since his metaphysics harbors a radical and quite disturbing form of negative theology. By separating the metaphysical Maimonides from the Maimonides of negative theology I show how Jewish negative theology culminates with an acknowledgment of the unique referential function of the proper name, a train of thought that takes a remarkably ethical turn with Levinas. Chapter 5 continues to explore Levinas's later philosophy by making explicit another major claim of this book, that what the philosopher calls "ethics" is best understood as a secularized and generalized account of the Jewish covenant of faith. I argue that Jewish faith ought to be understood phenomenologically rather than cognitively, and that theological beliefs, like moral and epistemic beliefs, are derived from the noncognitive experience of covenantal faith. Having outlined an account of ethics in terms of covenantal faithfulness, I turn, in Chapter 6, to the problem of political identity as it relates to Levinas's philosophy of Judaism.

Levinas's work is striking for the way it weaves together the secular and the religious, the Jewish and the Christian, the particular and the universal, the phenomenological and the hermeneutical. This is not a wild patchwork of postmodern syncretism but a testament to the implicatedness of thinking historically about our ethical and political condition to- 
xxvi Preface

gether. This implicatedness is not simply a banal historical fact but an ethical and political axiom with repercussions for how we think through and live our historical coexistence. Modern ethics does not stand on a neutral ahistorical platform, and it does not take place within natural borders or determinate historical and political identities. Today it is clear that our futures are inseparable, perilous, and absolutely unassured, and at the same time that we are moored to our origins far more than most modern thinkers imagined. Levinas's constant recourse to Judaism as a philosophical way of life springs from this very sentiment, which remains our predicament. Ethics happens as an exposure to singular demands in light of a heritage. But heritage is as unstable as it is unavoidable and as fiercely possessed as it is factually shared. Ethics thus inevitably involves a contestation over the goods we desire. The heterodoxy of Levinas's philosophy of Judaism, which eschews every strict division between the religious and the secular, Judaism and Christianity, Jew and Gentile, is both the source of its vitality and of its significance for the unforeseeable that faces us. 


\section{Acknowledgments}

Many people and institutions have enabled me to write this book. My studies led me from the Philosophy Department to the Centre for Comparative Literature and Cultural Studies, both at Monash University, and then to Jerusalem for several years where I studied at the Hebrew University of Jerusalem, the Shalom Hartman Institute, and as a Jerusalem Fellow at the Mandel Leadership Institute. I will single out only Kevin Hart, my PhD supervisor at Monash, who is now at the University of Virginia, and Moshe Halbertal, my mentor as a Golda Meir Postdoctoral Fellow at the Hebrew University of Jerusalem, although my gratitude extends to many scholars and administrators of those institutions. I am particularly aware that from my teachers in Jerusalem I have taken only what a paintbrush can take from the sea. Since returning to Monash University I have been involved in the establishment of the Australian Centre for Jewish Civilisation within the School of Historical Studies and have greatly benefited from the generous and supportive encouragement of my colleagues at Monash. I thank the administrative staff of the School of Historical Studies and the librarians at the Matheson Library who have greatly assisted me over the years. I thank also Mark Crees and James Cannon for providing me with valuable research assistance, and Andrew Markus and Mark Baker, the directors of the Australian Centre for Jewish Civilisation, for their support and trust.

Chapters 3 and 4 are modified versions of an article published in the Journal of Jewish Thought and Philosophy I6:I (2008). My thanks to Koninklijke Brill N.V. for allowing me to reprint the article. The arrival of Andrew Benjamin at Monash has been of great benefit and pleasure to me and I thank him for the attention and encouragement he has given my work. My thanks also go to members of the Phenomenology and Theology Research Group who read and commented on a couple of 
chapters. Emily-Jane Cohen at Stanford University Press provided much valuable assistance, as did Sarah Crane Newman, Carolyn Brown, and Alison Rainey.

It is a pleasure to acknowledge the unwavering support of my parents, Mark and Hannah Fagenblat. I am especially grateful to Naor Bar-Zeev and Nathan Wolski for innumerable conversations, references, criticisms, readings of my work, and, above all, friendship. To Melanie Landau I am grateful for the same, and a lot more. Our children, Ktoret and Ariel, provide a constant source of learning and delight. 
A COVENANT OF CREATURES 
